\title{
Too wet and too dry? Uncertainty of DEM as a potential source of significant errors in a model-based water level assessment in riparian and mire ecosystems
}

\author{
Dorota Mirosław-Świątek • Adam Kiczko • \\ Sylwia Szporak-Wasilewska • Mateusz Grygoruk
}

Received: 6 May 2016/Accepted: 13 February 2017/Published online: 21 February 2017

(C) The Author(s) 2017. This article is published with open access at Springerlink.com

\begin{abstract}
Modelling groundwater depths in floodplains and peatlands remains a basic approach to assessing hydrological conditions of habitats. Groundwater flow models used to compute groundwater heads are known for their uncertainties, and the calibration of these models and the uncertainty assessments of parameters remain fundamental steps in providing reliable data. However, the elevation data used to determine the geometry of model domains are frequently considered deterministic and hence are seldom considered a source of uncertainty in model-based groundwater level estimations. Knowing that even the cutting-edge laser-scanning-based digital elevation models have errors due to vegetation effects and scanning procedure failures, we provide an assessment of uncertainty of water level estimations that remain basic data for wetland ecosystem assessment and management. We found that the uncertainty of the digital elevation model (DEM) significantly influenced
\end{abstract}

D. Mirosław-Świątek $(\bowtie) \cdot$ A. Kiczko · M. Grygoruk Department of Hydraulic Engineering, Faculty of Civil, and Environmental Engineering, Warsaw University of Life Sciences - SGGW, ul. Nowoursynowska 159,

02-776 Warsaw, Poland

e-mail: d.swiatek@levis.sggw.pl

S. Szporak-Wasilewska

Water Centre Laboratory, Faculty of Civil and

Environmental Engineering, Warsaw University of Life

Sciences - SGGW, Ciszewskiego 6, 02-776 Warsaw,

Poland the results of the assessment of the habitat's hydrological conditions expressed as groundwater depths. In extreme cases, although the average habitat suitability index (HSI) assessed in a deterministic manner was defined as 'unsuitable', in a probabilistic approach (grid-cell-scale estimation), it reached a value of $40 \%$ probability, signifying 'optimum' or 'tolerant'. For the 24 habitats analysed, we revealed vast differences between HSI scores calculated for individual grid cells of the model and HSI scores computed as average values from the set of grid cells located within the habitat patches. We conclude that groundwater-modelling-based decision support approaches to wetland assessment can result in incorrect management if the quality of DEM has not been addressed in studies referring to groundwater depths.

Keywords Water level - Digital elevation model · DEM $\cdot$ Wetlands · Habitat conditions · Uncertainty

\section{Introduction}

Hydrological models are well-established tools applied over the years to simulate and predict the responses of ecosystems to water stress (Bradley 2002; Richter et al. 1996). Coupling cutting-edge hydrological models with advanced support originating from geographic information systems (GIS) and remote sensing (RS) that are integrated with ecological 
indicators allows the field of model-based analyses to expand into new dimensions, providing new and detailed information, which is required to broaden scientific knowledge of ecosystem functions (Berezowski et al. 2015; Grygoruk et al. 2014; Zhou et al. 2008). A particularly broad field in this regard covers the protection, management and restoration of mires and riparian wetlands, where strict hydrological criteria (water level distribution, duration of water levels, flood extents and volumes) must be fulfilled to assure sustainable habitat conditions or keep greenhouse gases emissions at an acceptable level (Chormański et al. 2009; Fortuniak et al. 2017; Grygoruk et al. 2015; Koreny et al. 1999; Mirosław-Świątek et al. 2016c; Vepraskas and Caldwell 2008). Special attention is paid to the requirements and tolerance of wetland vegetation species to a variability of water levels in a classical (phytosociological) approach (Caldwell et al. 2011). Moreover, the appropriate interpretation of water levels from a modern (traitbased) ecological approach appears to be even more important (Opdekamp et al. 2012). Either way, the most critical hydrological variables determining the status of riparian and mire ecosystems are associated with indices related to groundwater depths (e.g., average groundwater depth within the vegetation path, magnitude of water table fluctuations, minimum and maximum groundwater depths and duration of inundation).

Bearing in mind the possible errors that are associated with results of hydrological modelling, it is currently a standard procedure to assess the sensitivity of models with special regard to model parsimony and the uncertainty of the parameters applied. In this regard, groundwater flow models (e.g., MODFLOW-based or HYDRUS-based approaches) are subjected to a detailed estimation of prediction uncertainty (Hassan et al. 2008). Surprisingly, the most frequent approach is to disregard the uncertainty of the model domain. Among many sources of the uncertainty of groundwater models subjected to extended analysis (Wu and Zeng 2013), especially parameter identification, the influence of the model domain's uncertainty on modelling results has seldom been tested. In most studies in which the amount and direction of flows or water are the main point of interest, this factor seems to be insignificant, as it has only an indirect effect on the model performance. However, this is not so in the case of water-stress-oriented analyses conditioned mostly on groundwater depths. Here, model uncertainty might be strongly affected by the accuracy of elevation data, and serious methodological difficulties appear when different suitability classes of groundwater depths for certain plant communities fall inside of its confidence intervals. This is especially noticeable for riparian and mire ecosystems, in which the water table is relatively close to the terrain surface, and-importantly-such areas remain hardly accessible for elevation measurements due to a dense vegetation cover, which additionally underpins a relatively lower quality of elevation-assessment products such as digital elevation models (DEMs), even those developed with cutting-edge airborne laser scanning-light detection and ranging (ALS-LiDAR) methodology (MirosławŚwiątek et al. 2016b).

Our study attempts to answer the following research questions: (1) What are the differences between terrain elevations derived from ALS-LiDAR DEM compared to the DGPS-measured values within a lowland floodplain wetland? (2) Does the uncertainty of the groundwater flow model domain, herein referred to as the uncertainty of terrain elevation data, affect modelled values of total hydraulic heads? (3) Is the uncertainty of ALS-LiDAR DEM dependent on land cover type? (4) Is a deterministic approach to the GIS-based and model-based analysis of groundwater depths suitable and reliable enough to be used for ecological purposes such as the reliable assessment of water-level-related habitat indicators? In our paper, we present a detailed study from a complex, temperate European floodplain-mire wetland located in the Biebrza Valley (Poland).

\section{Materials and methods}

\section{Study area}

Our study was conducted in the northern stretch of the Lower Basin of the Biebrza Valley (Fig. 1a, b), located in northeastern Poland, which is one of the most famous and ecologically valuable mosaics of riparian and mire ecosystems of Europe (Wassen et al. 2006). The research site is a broad land depression that was shaped in the late Pleistocene by fluvio-glacial waters of the Vistulian Glaciation. The valley is approximately $5 \mathrm{~km}$ wide and is filled with sand, on 


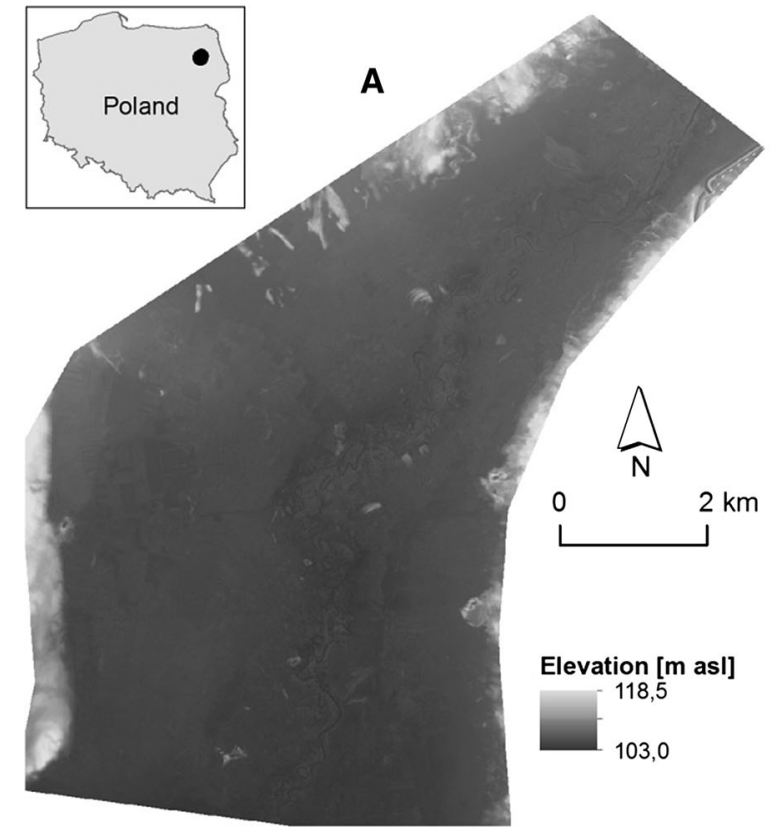

Fig. 1 Study area-Northern part of the Lower Basin of the Biebrza Valley. a Digital Elevation Model (0.6 m spatial resolution) after Mirosław-Świątek et al. (2016b); b distribution of ground elevation measurements in various classes of land cover (plant communities): 1 Caricetum appropinquatae, 2

which peat soils of a maximum thickness of $3 \mathrm{~m}$ developed in the Holocene. Terrain elevations in the study area vary from 103 to $118.5 \mathrm{~m}$ a.s.l. (the latter beyond the river valley). The area is regularly flooded (Grygoruk et al. 2013), consists of numerous natural floodplain lakes (Slapinska et al. 2016), and the main source of water supply to wetlands of this part of the Biebrza Valley is flooding originating from the Biebrza River. The average discharge of the Biebrza River in the stretch analysed reached approximately $22.4 \mathrm{~m}^{3} / \mathrm{s}$ (Grygoruk et al. 2011). Groundwater levels in the riparian habitats analysed vary from permanent inundation in spring (flood depths up to $1.5 \mathrm{~m}$ within the floodplain) down to $1.5 \mathrm{~m}$ below the ground in the driest periods. The average annual air temperature is equal to $6.6{ }^{\circ} \mathrm{C}$ (Banaszuk 2004), and the average annual total precipitation is as high as $560 \mathrm{~mm}$ (Kossowska-Cezak 1984). The area of the valley is densely vegetated by typical riparian plant communities such as sedges, reed-manna grass, reeds, willow and alder shrubs and forests (Fig. 1b).

The majority of the study area is agriculturally managed as extensively used meadows of a seasonal mowing regime, but the vegetation remains near

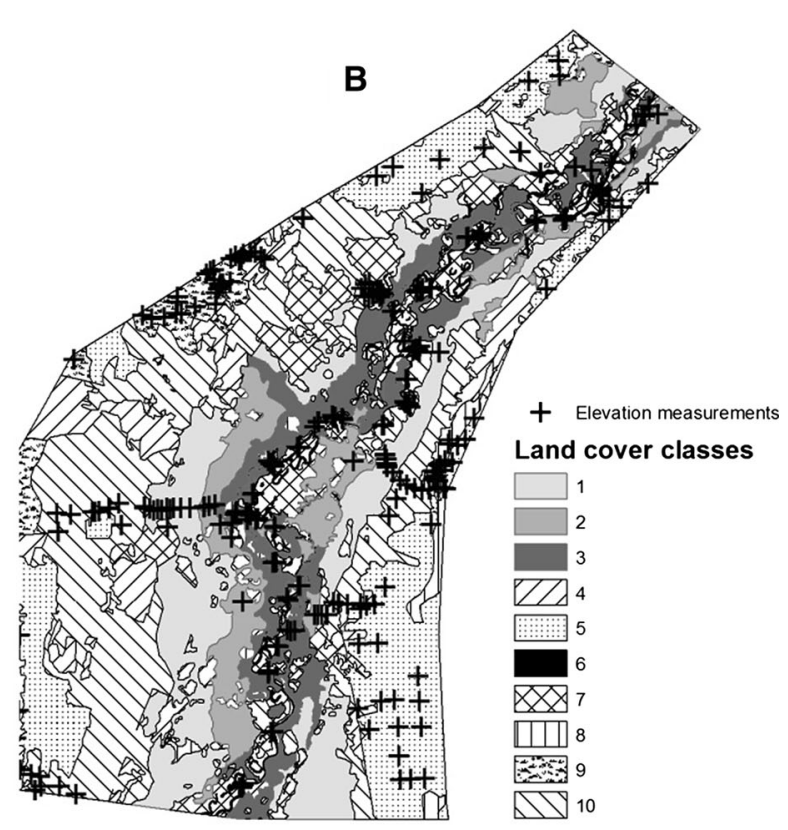

Caricetum gracilis, 3 Glycerietum maximae, 4 Alder and Willow encroachments, 5 mixed forest, 6 water, 7 Phragmitetum australis, 8 mown meadow and pasture, 9 mosaic of loose tussock sedges and grasses, 10 mosaic of loose tussock and tussock sedges

natural; no new species have been introduced for agricultural purposes. Additionally, the entire area analysed remains covered by Natura 2000 protection both as a special area of protection (SAP) and as an area of special protection of species (ASP). Biebrza Valley is known for its unique features as a migratory bird habitat (Polakowski et al. 2014) and as an ultimate area of protection of valuable and rare species of birds connected to wetlands (Maciorowski et al. 2014; Oppel et al. 2014). Specific actions related to the appropriate management of this area, such as broad-scale largetrack mowing, are considered influential to the microtopography of the wetlands analysed (Banaszuk et al. 2016; Kotowski et al. 2013;), which additionally justifies the need for detailed research on the accuracy of the numerical topographic data for ecohydrological purposes that we undertake in our analysis.

\section{Selection of habitats for the analysis}

The key issue of our research was to reveal how the uncertainty of DEM affects the predicted hydrological conditions of habitats using the total hydraulic head computed using the groundwater model. In this regard, 
we selected individual patches of habitats that had different vegetation structure and could had been characterized with the presence of different species of birds. The habitats selected were categorized into 9 different vegetation types and open water, which was later not considered in our analysis (ref. Fig 1b), namely Caricetum appropinquatae, Caricetum gracilis, Glycerietum maximae, Phragmitetum australis, a mosaic of alder and willow encroachments, mixed forest, mown meadow/grazed pasture, a mosaic of loose tussock and tussock sedges and a mosaic of loose tussock sedges and grasses. Vegetation type classes were delineated on the basis of field measurements and airborne and satellite optical imagery using objectbased image analysis (OBIA) by Mirosław-Światek et al. (2016b). The vegetation map was intersected with the preliminary map of Natura 2000 bird species distribution in order to obtain habitat patches consisting of selected vegetation and potential presence of selected birds (BNP 2015). In our analysis, we focused on specific bird species, the behaviour of which is related to particular hydrological conditions (waterlogging, shallow groundwater level), namely Anser albifrons, Aquila clanga, Crex crex, Gallinago gallinago, Porzana porzana and Acrocephalus paludicola. All of the selected bird species represent different behavioural and foraging groups and cover the most representative species present within the Biebrza Valley. Spatial analysis allowed us to select 24 individual patches of habitats with different hydrological requirements (Table 1; Fig. 2a). For each of the habitats we assigned a range of optimum (OPT) and tolerant (TOL) groundwater depths, referred to as the habitat suitability index (HSI) (Table 1). These values were assigned in an arbitrary manner based upon available water-level monitoring data and information on the habitat requirements of both plants and birds and were spatially intersected with maps of groundwater-level monitoring in the Lower Biebrza Basin (Grygoruk 2013; Grzywaczewski et al. 2014; Grzywaczewski et al. 2017; Maciorowski et al. 2014; Okruszko 2005; Oppel et al. 2014; Polakowski et al. 2014).

It must be noted that any measure similar to the HSI might be affected by averaging input values. The score can be elaborated for distributed input but also averaged over a larger area. In the first case, the measure is evaluated for all point values and then averaged, whereas in the second, the averaging is performed prior to summarizing the areas of habitats. We discuss this issue by comparing the mean of the HSI obtained for water depths at model nodes for a habitat (HSI for point values) with that computed for values averaged over a habitat area (HSI for habitataveraged water levels).

One should consider the given values of HSI as being indicative only. The given criteria are used in our study as a locally relevant approximation of the hydrological conditions of the habitats analysed. These criteria were used for the analysis of the possible influence of DEM on the final results of hydrological analysis. Although we used local references for wetland habitat criteria, the direct values of tolerant and optimum water levels in riparian wetlands and mires worldwide tend to be at similar levels of magnitude (Mitsch and Gosselink 2015).

Assessment of DEM accuracy in various habitats

ALS-LiDAR methodology and object-based image analysis (OBIA) was applied to develop a high-quality DEM of the research area with the spatial resolution of $1 \mathrm{~m}$ (Mirosław-Świątek et al. 2016b). It involved the combined use of airborne and optical satellite imagery, real-time kinematic GNSS (RTK GNSS) elevation measurements, topographical surveys and vegetation height measurements to correct the socalled 'vegetation effect' present in ALS LiDAR DEMs resulting from the falsification of terrain elevations caused by very dense wetland vegetation.

One of the goals of our study was to provide a comparative analysis of ALS-LiDAR DEM accuracy compared with field measurements (Fig. 1a) within the extent of various types of land cover (vegetation classes). In the ranges selected, 10 vegetation classes at scattered points (Fig. 1b), we compared fieldmeasured and DEM-derived terrain elevations. The terrain elevations used in the comparative study were measured with the use of the DGPS methodology and resulted in elevation measurements with accuracy as high as $\pm 0.02 \mathrm{~m}$ (Mirosław-Świątek et al. 2016a). The individual value, which in the comparative analysis is considered as a local field measurement (Fig. 1b), due to the microtopography of the wetland analysed, was assessed as an average terrain elevation calculated on the basis of multiple representative point measurements done within the area of $625 \mathrm{~m}^{2}$ $(25 \mathrm{~m} \times 25 \mathrm{~m}$ - the area of the DEM grid cell). On 
Table 1 Ecological and hydrological features of selected habitats

\begin{tabular}{|c|c|c|c|c|c|c|c|c|c|}
\hline \multirow[t]{2}{*}{ Hab. } & \multicolumn{6}{|c|}{ Bird species } & \multirow[t]{2}{*}{ Vegetation } & \multicolumn{2}{|l|}{ HSI [m bgl] } \\
\hline & AA & $\mathrm{AC}$ & $\mathrm{CX}$ & GG & PP & XD & & OPT & TOL \\
\hline 1 & & & $\mathrm{x}$ & $\mathrm{x}$ & & & Caricetum appropinquatae & -0.5 to 0 & -0.6 to 0.15 \\
\hline 2 & & $\mathrm{x}$ & & & $\mathrm{x}$ & & Caricetum appropinquatae & -0.4 to -0.1 & -0.8 to 0.15 \\
\hline 3 & $\mathrm{x}$ & & $\mathrm{x}$ & $\mathrm{x}$ & $\mathrm{x}$ & & Caricetum appropinquatae & -0.5 to 0 & -0.6 to 0.15 \\
\hline 4 & $\mathrm{x}$ & & & $\mathrm{x}$ & & & Caricetum appropinquatae & -0.5 to 0 & -0.6 to 0.15 \\
\hline 5 & $\mathrm{x}$ & & $\mathrm{x}$ & $\mathrm{x}$ & & & Caricetum appropinquatae & -0.4 to -0.1 & -0.8 to 0.15 \\
\hline 6 & $\mathrm{x}$ & & $\mathrm{x}$ & & $\mathrm{x}$ & $\mathrm{x}$ & Caricetum appropinquatae & -0.4 to -0.1 & -0.8 to 0.15 \\
\hline 7 & & & & & $\mathrm{x}$ & & Caricetum gracilis & -0.5 to 0 & -0.6 to 0.15 \\
\hline 8 & $\mathrm{x}$ & & & $\mathrm{x}$ & & $\mathrm{x}$ & Caricetum gracilis & -0.4 to -0.1 & -0.8 to 0.15 \\
\hline 9 & $\mathrm{x}$ & & & $\mathrm{x}$ & $\mathrm{x}$ & & Glycerietum maximae & -0.4 to -0.1 & -0.8 to 0.15 \\
\hline 10 & $\mathrm{x}$ & & & $\mathrm{x}$ & & & Glycerietum maximae & -0.4 to -0.1 & -0.8 to 0.15 \\
\hline 11 & $\mathrm{x}$ & & & $\mathrm{x}$ & & & Glycerietum maximae & -0.4 to -0.1 & -0.8 to 0.15 \\
\hline 12 & $\mathrm{x}$ & $\mathrm{x}$ & $\mathrm{x}$ & & $\mathrm{x}$ & & Glycerietum maximae & -0.5 to 0 & -0.6 to 0.15 \\
\hline 13 & & $\mathrm{x}$ & $\mathrm{x}$ & $\mathrm{x}$ & $\mathrm{x}$ & & Mosaic of alder and willow encroachments & -0.15 to 0 & -0.25 to -0.15 and 0 to 0.1 \\
\hline 14 & $\mathrm{x}$ & & $\mathrm{x}$ & $\mathrm{x}$ & & $\mathrm{x}$ & Mosaic of alder and willow encroachments & -0.15 to 0 & -0.25 to -0.15 and 0 to 0.2 \\
\hline 15 & & & & $\mathrm{x}$ & $\mathrm{x}$ & & Mosaic of alder and willow encroachments & -0.15 to 0 & -0.25 to -0.15 and 0 to 0.3 \\
\hline 16 & & $\mathrm{x}$ & & & & & Mixed forest & -0.5 to 0 & -0.6 to 0.15 \\
\hline 17 & & $\mathrm{x}$ & & & & & Mosaic of alder and willow encroachments & -0.15 to 0 & -0.25 to -0.15 and 0 to 0.3 \\
\hline 18 & & & & & $\mathrm{x}$ & & Phragmitetum australis & -0.2 to 0.4 & -0.3 to -0.6 \\
\hline 19 & $\mathrm{x}$ & $\mathrm{x}$ & & & $\mathrm{x}$ & & Phragmitetum australis & -0.2 to 0.5 & -0.3 to -0.6 \\
\hline 20 & $\mathrm{x}$ & $\mathrm{x}$ & & & & & Mown meadow/pasture & -0.4 to -0.1 & -0.8 to 0.15 \\
\hline 21 & $\mathrm{x}$ & & & $\mathrm{x}$ & $\mathrm{x}$ & & Mixed sedges and grasses & -0.5 to 0 & -0.6 to 0.15 \\
\hline 22 & & & & $\mathrm{x}$ & $\mathrm{x}$ & & Mosaic of loose tussock and tussock sedges & -0.5 to 0 & -0.6 to 0.15 \\
\hline 23 & & & $\mathrm{x}$ & $\mathrm{x}$ & $\mathrm{x}$ & & Mosaic of loose tussock and tussock sedges & -0.15 to 0 & -0.25 to -0.15 and 0 to 0.3 \\
\hline 24 & $\mathrm{x}$ & $\mathrm{x}$ & & & $\mathrm{x}$ & & Mosaic of loose tussock and tussock sedges & -0.15 to 0 & -0.25 to -0.15 and 0 to 0.3 \\
\hline
\end{tabular}

Bird species: $A A$ Anser albifrons, $A C$ quila clanga, $C X$ Crex crex, $G G$ Gallinago gallinago, $P P$ Porzana porzana, $X D$ Acrocephalus paludicola. Delineation of vegetation types and bird species occurrence was specified on the basis of the Natura 2000 protection plan for the Biebrza Valley (BNP 2015)

the basis of differences between the measured and DEM-derived values, we assessed the mean errors of estimation and standard deviations of differences, which were later used as DEM uncertainty boundaries in a Monte Carlo analysis.

\section{Groundwater flow model description}

The simple groundwater flow model developed was based on the MODFLOW code (Harbaugh 2005). The model was developed and executed in the ModelMuse Graphical User Interface (Winston 2009). The model covered the entire area of research (ref. Figs 1, 2a) with a grid mesh of $25 \mathrm{~m} \times 25 \mathrm{~m}$, amounting to 441 by 407 (no. of rows by no. of columns) cells. Vertical discretization of the model domain was performed according to the changing lithological structure and consisted of 3 layers representing variably saturated peat (the superficial layer of the model), saturated peat (the middle layer of the model) and saturated sand (the bottommost layer of the model). These layers were simulated as convertible (topmost peat) and confined (deeper peat and sand). A similar setup of model layers was proven to be relevant for the field conditions of the Biebrza Valley (Grygoruk et al. 2014; Grygoruk et al. 2015). For the purpose of our study, we executed the model in a steady state because only the specific situation of the average multi-year hydrologic 

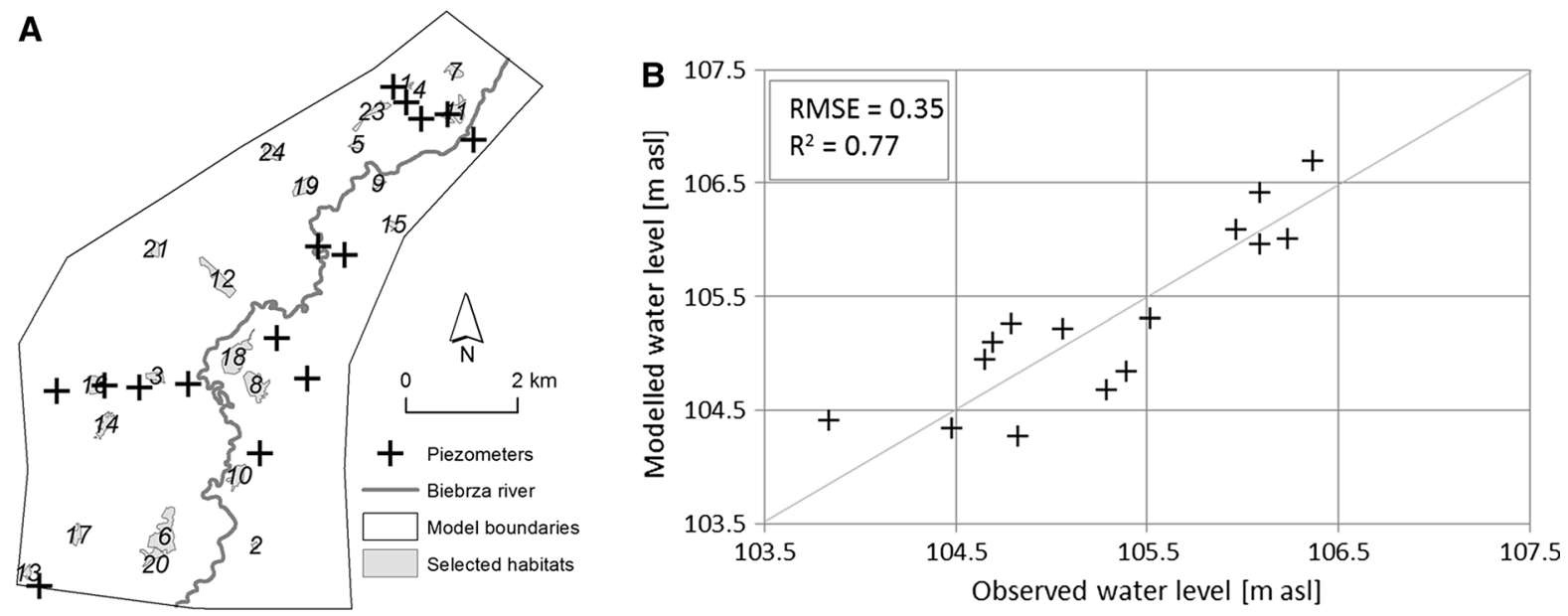

Fig. 2 Groundwater flow model calibration results. a locations of piezometers used for model calibration and habitats selected for the hydrological analysis; b calibration plot

conditions was needed. The boundary conditions of the model included a simulation of groundwater recharge, river-aquifer interactions and groundwater inflow to the valley from adjacent plateaus. Groundwater recharge was simulated with the $\mathrm{RCH}$ package.

The value of groundwater recharge was calculated on the basis of precipitation, interception, evapotranspiration and surface runoff externally from the model in a GIS-based spatial approach and reached levels as high as $135 \mathrm{~mm} /$ year. Interaction between the river and groundwater was simulated with the RIV package. Elevations of the water table along the river were linearly interpolated on the basis of field measurements of the water level. The depths of the river were assigned to each of the RIV-package-related model cells on the basis of field-measured data from 35 river channel cross sections. In all of the cells with the active RIV package, the measured bottom of the river was situated below the peat bottom, which indicated good hydraulic connectivity of the river and groundwater of the sandy aquifer, which remains the most important source of groundwater on the regional scale. We assumed that the layer of river bed sediments was $1 \mathrm{~m}$ deep, and its hydraulic conductivity is one order of magnitude lower than the hydraulic conductivities of the sandy aquifer, which was tested and proven to be appropriate for the Biebrza Valley groundwater system by Bleuten and Schermers (1994) and Batelaan and Kuntohadi (2002). Lateral inflow to the valley was simulated with the CHD package. The values of water levels along the external ( $\mathrm{E}$ and $\mathrm{W}$ ) boundaries of the model domain were assigned on the basis of field observations in 11 piezometers distributed uniformly along the model boundaries. Model calibration was done with the use of field-measured data of groundwater levels in 15 piezometers (Fig. 2a). The root mean squared error (RMSE) of modelled versus observed groundwater levels reached $0.35 \mathrm{~m}$, and the determination coefficient $\left(\mathrm{R}^{2}\right)$ was equal to 0.77 , which was considered satisfactory given the low variability of the groundwater table throughout the modelled area. The calibrated values of the hydraulic conductivities of particular layers were as high as $0.223 \mathrm{~m} / \mathrm{d}$ for the topmost peat, $0.110 \mathrm{~m} / \mathrm{d}$ for the saturated peat and $13.2 \mathrm{~m} / \mathrm{d}$ for the saturated sand. The map of the total hydraulic head of the groundwater table produced with the use of the developed model was used in the assessment of the DEM's uncertainty influence on modelled wetland habitat conditions.

\section{Uncertainty assessment approach}

We investigated the transformation of the uncertainty of the DEM influencing the groundwater flow model. The DEM's uncertainty is considered here in a probabilistic manner, in which an elevation at each grid node is disturbed by a random term $e$ (Hunter and Goodchild 1997):

$Z_{i, j}=\hat{Z}_{i, j}+e$

where $Z_{i, j}$ denotes the elevation at the $(\mathrm{i}, \mathrm{j})$ node and $\hat{Z}_{i, j}$ the nominal DEM value. It is assumed that the 
disturbance term $e$ is independent and follows a normal distribution $e \sim N\left(0, \sigma_{k}\right)$. The variance $\sigma_{k}^{2}$ depends on the local DEM accuracy, assessed for each k-th habitat class (Table 2). It can be expected that errors in DEM elevations are spatially dependent (Hunter and Goodchild 1997; Aguilar et al. 2010). However, as the identification of the errors' autocorrelation is a difficult task and requires many measurement locations, the assumption of the independent disturbance term used here is common in similar studies (e.g., Liu et al. 2012).

The effect of the DEM uncertainty was analysed for direct outcomes of the groundwater model-groundwater table elevations $H$ and depth $h$-and derived from the water table depth, the HSI. The first outcome, groundwater elevation $H$, does not depend explicitly on the terrain surface and can be considered a measure of the effect of DEM uncertainty on the hydraulic properties of the aquifer. The second outcome, the depth to the water table, defined as the difference between the DEM elevation and the ground water elevation at the given grid node $h_{i, j}=Z_{i, j}-H_{i, j}$ explicitly incorporates the DEM disturbance term e: $h_{i, j}=\hat{Z}_{i, j}-H_{i, j}+e$. Last, the HSI is a piecewise linear function of $h$.
Comparing the input and output variations, it is possible to assess the sensitivity of the output on introduced disturbances (Archer et al. 1997). High variation suggests a strong influence of DEM uncertainty. Conversely, low variation indicates low sensitivity. Moreover, adding the uncertainty term might lead to a different solution from that based on the nominal values of the DEM. With linear transformations, it is expected that the disturbances do not affect the output mean value:

$E(M(Z))=M(E(Z))$

where $\mathrm{M}(\cdot)$ stands for the model output, $\mathrm{E}(\cdot)$ is the expectation operator and $\mathrm{Z}$ is a grid matrix of disrupted DEM elevations (eq. Text, note $E(Z)=\hat{Z}$ ). The equation might not necessarily be true, which suggests the presence of non-linear effects that affect the transformation of the uncertainty (Kiczko et al. 2013; Brandyk et al. 2016; Romanowicz and Kiczko 2016). The transformation of DEM uncertainty to the distribution of the outcome values representing hydrological conditions of wetland habitats was investigated using Monte Carlo sampling with 10,000 model realizations. Statistical analyses were performed with respect to habitat classes and characterized by different levels of accuracy of the DEM. The output

Table 2 Differences of field-measured versus ALS-LiDAR DEM-derived ground elevations in selected land cover (vegetation type) classes

\begin{tabular}{|c|c|c|c|c|c|c|}
\hline $\begin{array}{l}\text { Class } \\
\text { no. }\end{array}$ & Description & $\begin{array}{l}\text { Number of } \\
\text { comparative } \\
\text { measurements }\end{array}$ & $\begin{array}{l}\text { Average error of } \\
\operatorname{DEM}(\mathrm{m})\end{array}$ & $\begin{array}{l}\text { Mean absolute error } \\
\text { of DEM }(\mathrm{m})\end{array}$ & $\begin{array}{l}\text { Max. absolute error } \\
\text { of DEM (m) }\end{array}$ & $\begin{array}{l}\sigma_{k} \\
(\mathrm{~m})\end{array}$ \\
\hline 1 & $\begin{array}{l}\text { Caricetum } \\
\text { appropinquatae }\end{array}$ & 22 & -0.10 & 0.52 & 1.27 & 0.69 \\
\hline 2 & Caricetum gracilis & 18 & 0.19 & 0.23 & 0.18 & 0.26 \\
\hline 3 & Glycerietum maximae & 55 & 0.16 & 0.26 & 0.61 & 0.33 \\
\hline 4 & $\begin{array}{l}\text { Alder and Willow } \\
\text { encroachments }\end{array}$ & 29 & 0.24 & 0.32 & 0.47 & 0.35 \\
\hline 5 & Mixed forest & 36 & -0.16 & 0.40 & 1.63 & 0.60 \\
\hline 7 & Phragmitetum australis & 57 & 0.15 & 0.34 & 0.66 & 0.40 \\
\hline 8 & $\begin{array}{l}\text { Mown meadow/grazed } \\
\text { pasture }\end{array}$ & 34 & -0.38 & 0.77 & 1.75 & 0.84 \\
\hline 9 & $\begin{array}{l}\text { Mosaic of loose } \\
\text { tussocksedges and } \\
\text { grasses }\end{array}$ & 28 & -0.18 & 0.33 & 1.73 & 0.49 \\
\hline 10 & $\begin{array}{l}\text { Mosaic of loose } \\
\text { tussockand tussock } \\
\text { sedges }\end{array}$ & 63 & 0.15 & 0.27 & 0.89 & 0.30 \\
\hline
\end{tabular}


uncertainty was investigated for the spatially distributed output of the model and values were averaged over an area of a certain plant community.

\section{Results}

Elevation differences in selected land cover classes: ALS-LiDAR versus DGPS

A comparison of field-measured to DEM-derived elevations of the riparian wetland analysed showed variable discrepancies (Table 2). The best fit of DEM to field-measured data was recorded with extents of Caricetum gracilis (MAE $=0.23 \mathrm{~m} ; \sigma_{k}=0.26 \mathrm{~m}$ ), Glycerietum maximae (MAE $=0.26 \mathrm{~m} ; \sigma_{k}=0.33 \mathrm{~m}$ ) and a mosaic of loose tussock and tussock sedge vegetation $\left(\mathrm{MAE}=0.27 \mathrm{~m} ; \sigma_{k}=0.30 \mathrm{~m}\right)$. The highest discrepancies between the field-measured and DEM-derived ground elevations were surprisingly recorded within mown meadows/grazed pastures $\left(\mathrm{MAE}=0.77 \mathrm{~m} ; \sigma_{k}=0.84 \mathrm{~m}\right)$, Caricetum appropinquatae (MAE $=0.52 \mathrm{~m} ; \sigma_{k}=0.69 \mathrm{~m}$ ) and mixed forest (MAE $=0.40 \mathrm{~m} ; \sigma_{k}=0.60 \mathrm{~m}$ ).

Values of $\sigma_{k}$ calculated on the basis of obtained elevation differences were used in a DEM disturbance uncertainty analysis: the transformation of DEM in Monte Carlo sampling was done in the interval of $\sigma_{k}$ within the extents of particular land cover (vegetation type) classes (see Fig. 1b).

Influence of DEM uncertainty on habitat parameter assessment

The effect of the DEM disturbance on the calculated total hydraulic heads $H$ (groundwater elevations; Fig. 3a) was found to be unnoticeable. The standard
Fig. 4 Calculated frequencies (horizontal bars) of the depth to the groundwater table $\mathrm{h}$ and HSI classes (gray continuous line) for two plant communities. The dashed line shows the depth for undisrupted DEM. a Habitat Caricetum appropinquatae (no. 2); b Caricetum appropinquatae (no. 3); c Caricetum appropinquatae (no. 5); d Caricetum appropinquatae (no. 6); e Caricetum gracilis (no. 8); f Glycerietum maximae (no. 12)

deviation of $H$ did not exceed the value of $3 \mathrm{~mm}$ within all of the plant communities analysed. This observation allowed us to conclude that hydrological analysis of groundwater depths in wetlands, which is done with the use of trustworthy elevation data (e.g., field measurements) and spatially diverse $H$ that remain an output from the groundwater flow model (such as the MODFLOW-based approach presented herein), remains a reliable source of data on the hydrological conditions of habitats. This was different in the case of outcomes that directly depended on the DEM elevations: depth to the groundwater table $h$ (Fig. 3b) and the HSI. The depth $h$, because groundwater elevations $H$ remain almost constant in all samples, has the same uncertainty pattern as the DEM, with the disturbance term $e$. The computed standard deviations are equal to the assumed standard deviations of the DEM elaborated for each plant community. In Fig. 4, the frequencies of calculated groundwater depths averaged over the habitat area are shown along with the piecewise function of the HSI. As expected, the distribution of $h$ mostly follows the normal distribution of the disturbance $e$. Depths marked with dashed lines obtained using undisrupted DEM elevations usually fall in the middle of the sample. This is different for areas in which the water table was close to the surface, as in the case of habitat of mixed forest (no. 5, Fig. 4c), where the seminormal distribution is affected by the constraint
A

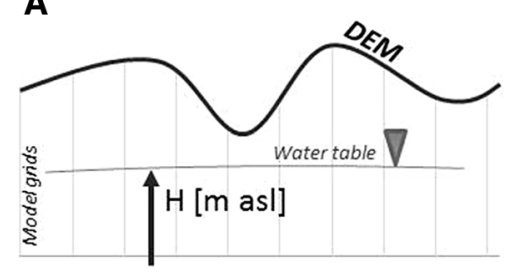

B

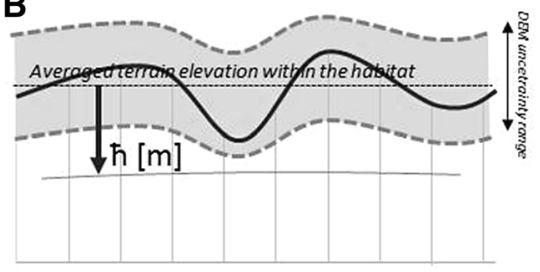

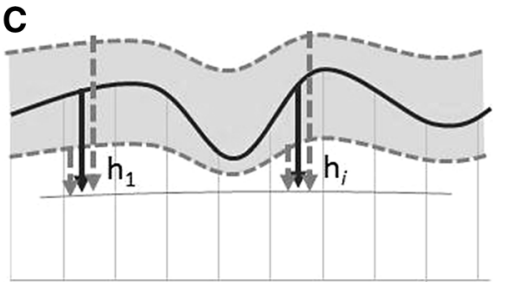

Fig. 3 Habitat conditions analysed in the study: a total hydraulic head of groundwater, b average groundwater depth within the whole habitat calculated as a mean value of groundwater depths $\left(h_{i}\right.$ for $\left.\mathrm{i}=1, \ldots, \mathrm{N}\right)$ where $\mathrm{N}$ is the summary number of cells in the habitat, $\mathbf{c}$ groundwater depth in every grid cell that belongs to the habitat. Gray zone stands for the uncertainty of DEM 

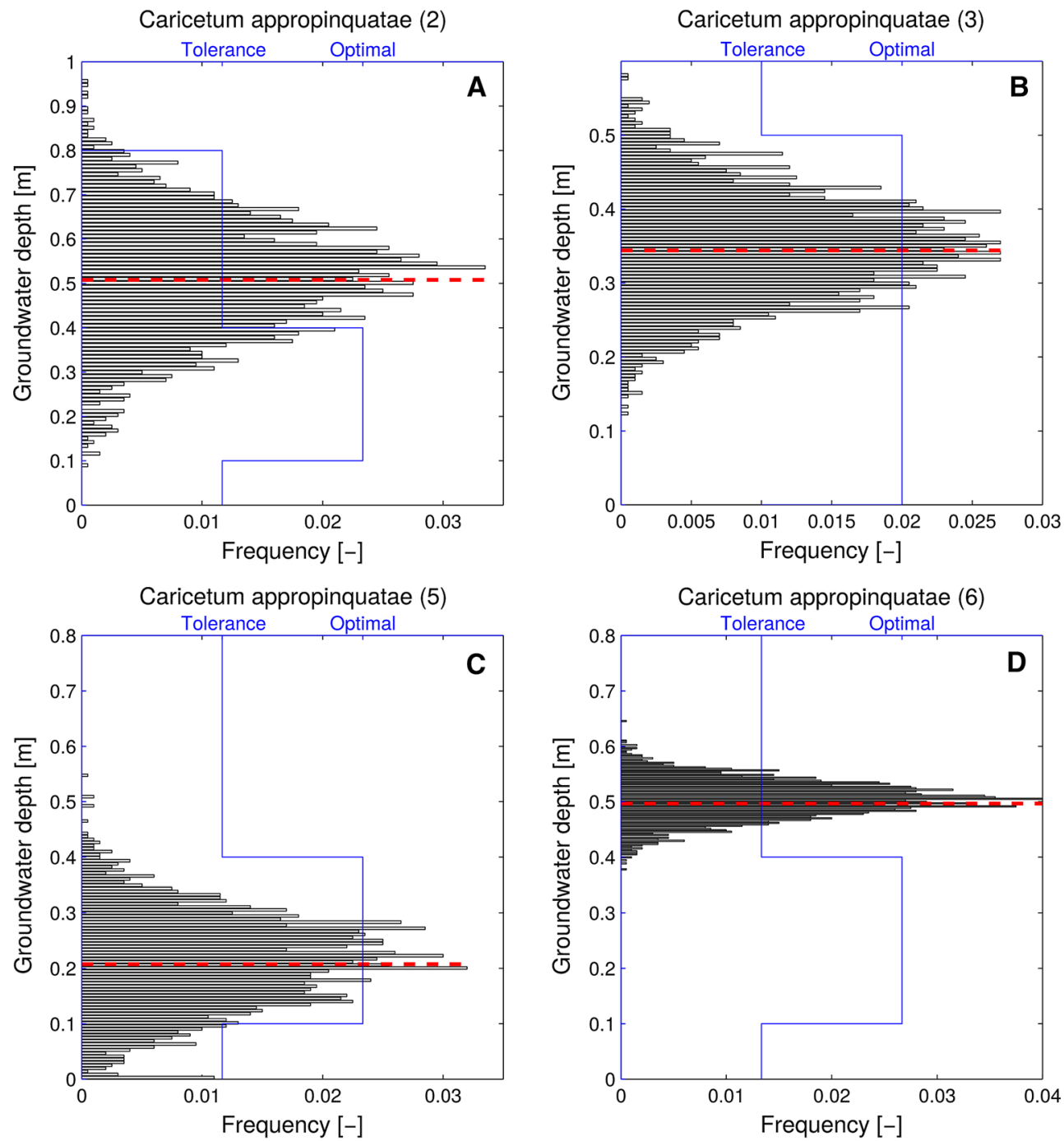

Caricetum gracilis (8)
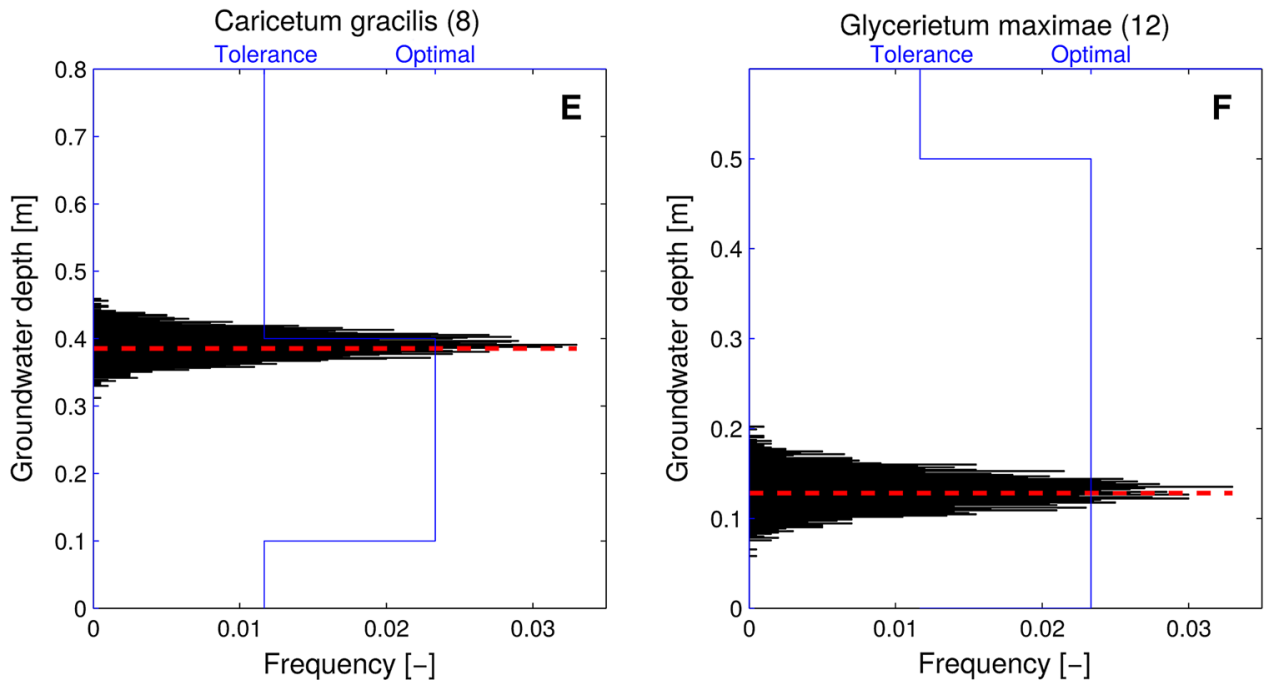
Table 3 The confidence of HSI, accounting for the DEM uncertainty

\begin{tabular}{|c|c|c|c|c|c|}
\hline \multirow[t]{2}{*}{ Habitat } & \multicolumn{2}{|c|}{ Probability of $h$ in grid nodes } & \multicolumn{2}{|c|}{ Probability of $h$ averaged over communities area } & \multirow[t]{2}{*}{ HSI for undisrupted DEM } \\
\hline & HSI Tolerance & HSI Optimum & HSI Tolerance & HSI Optimum & \\
\hline 1 & 0.53 & 0.27 & 0.01 & 0.99 & Optimum \\
\hline 2 & 0.50 & 0.16 & 0.79 & 0.20 & Tolerance \\
\hline 3 & 0.36 & 0.28 & 0.02 & 0.98 & Optimum \\
\hline 4 & 0.49 & 0.28 & 0.00 & 0.99 & Optimum \\
\hline 5 & 0.63 & 0.17 & 0.12 & 0.88 & Optimum \\
\hline 6 & 0.51 & 0.16 & 1.00 & 0.00 & Tolerance \\
\hline 7 & 0.25 & 0.53 & 0.00 & 1.00 & Optimum \\
\hline 8 & 0.57 & 0.33 & 0.35 & 0.65 & Optimum \\
\hline 9 & 0.52 & 0.21 & 1.00 & 0.00 & Tolerance \\
\hline 10 & 0.34 & 0.09 & 0.00 & 0.00 & Unsuitable \\
\hline 11 & 0.52 & 0.22 & 1.00 & 0.00 & Tolerance \\
\hline 12 & 0.41 & 0.50 & 0.00 & 1.00 & Optimum \\
\hline 13 & 0.29 & 0.13 & 0.05 & 0.00 & Unsuitable \\
\hline 14 & 0.50 & 0.17 & 0.03 & 0.97 & Optimum \\
\hline 15 & 0.23 & 0.11 & 0.00 & 0.00 & Unsuitable \\
\hline 16 & 0.52 & 0.30 & 0.00 & 1.00 & Optimum \\
\hline 17 & 0.43 & 0.10 & 0.53 & 0.20 & Tolerance \\
\hline 18 & 0.06 & 0.04 & 0.00 & 0.00 & Unsuitable \\
\hline 19 & 0.21 & 0.12 & 0.00 & 0.00 & Unsuitable \\
\hline 20 & 0.32 & 0.10 & 0.01 & 0.00 & Unsuitable \\
\hline 21 & 0.40 & 0.39 & 0.00 & 1.00 & Optimum \\
\hline 22 & 0.54 & 0.35 & 0.00 & 1.00 & Optimum \\
\hline 23 & 0.55 & 0.14 & 0.00 & 1.00 & Optimum \\
\hline 24 & 0.30 & 0.12 & 0.01 & 0.00 & Unsuitable \\
\hline
\end{tabular}

Habitat: 1-6 Caricetum appropinquatae; 7-8 Caricetum gracilis; 9-12 Glycerietum maximae; 13-15, 17 mosaic of alder and willow encroachments; 16 mixed forest; 18-19 Phragmitetum australis; 20 Mown meadow/pasture; 21 mixed sedges and grasses; 22-24 mosaic of loose tussock and tussock sedges

limiting it to the positive values $\left(h_{i, j} \geq 0\right)$, resulting in a peak at the zero height. The uncertainty of the depths $h$ significantly affects the HSI scores due to their nonlinear form. For an example, in Fig. 4a, the undisturbed water depth (for nominal elevations of the DEM) is identified as being within a tolerance of habitat no. 2 (Caricetum appropinquatae, Fig. 4c). This agrees with the frequency bars, which indicate that most of the water depths disturbed with the DEM fall into that category. However, due to the uncertainty, the optimal conditions cannot be excluded, as almost $20 \%$ of the samples are present in that class. This is even more noticeable in Fig. $4 b$, where the depth of the nominal DEM elevations is close to the limit of the class of optimum conditions, and the probabilistic solution suggests that less favourable conditions might be present. In joining information on frequencies of groundwater depths with intervals of HSI classes, it is possible to calculate the overall probability of the given HSI score. In Table 3, the confidence values of the HSI score are elaborated in this manner and given for each vegetation class, both for habitat-averaged and point values of the groundwater depth $h$. The score of HSI for undisrupted DEM was calculated as a mean value of groundwater depths for all grid cells belonging to a particular habitat (Fig. 3a). In the case of groundwater depths with the disrupted DEM applied, the probability of the particular average values of $h$ was assessed (Fig. 3b). The probability of reaching a particular value of $h$ was also analysed for individual grid cells belonging to the particular habitat (Fig. 3c). For numerous vegetation 
Fig. 5 Probability of reaching optimal $(\mathbf{a}, \mathbf{d})$, tolerant $(\mathbf{b}, \mathbf{e})$ and unsuitable (c, f) groundwater levels within the habitats analysed
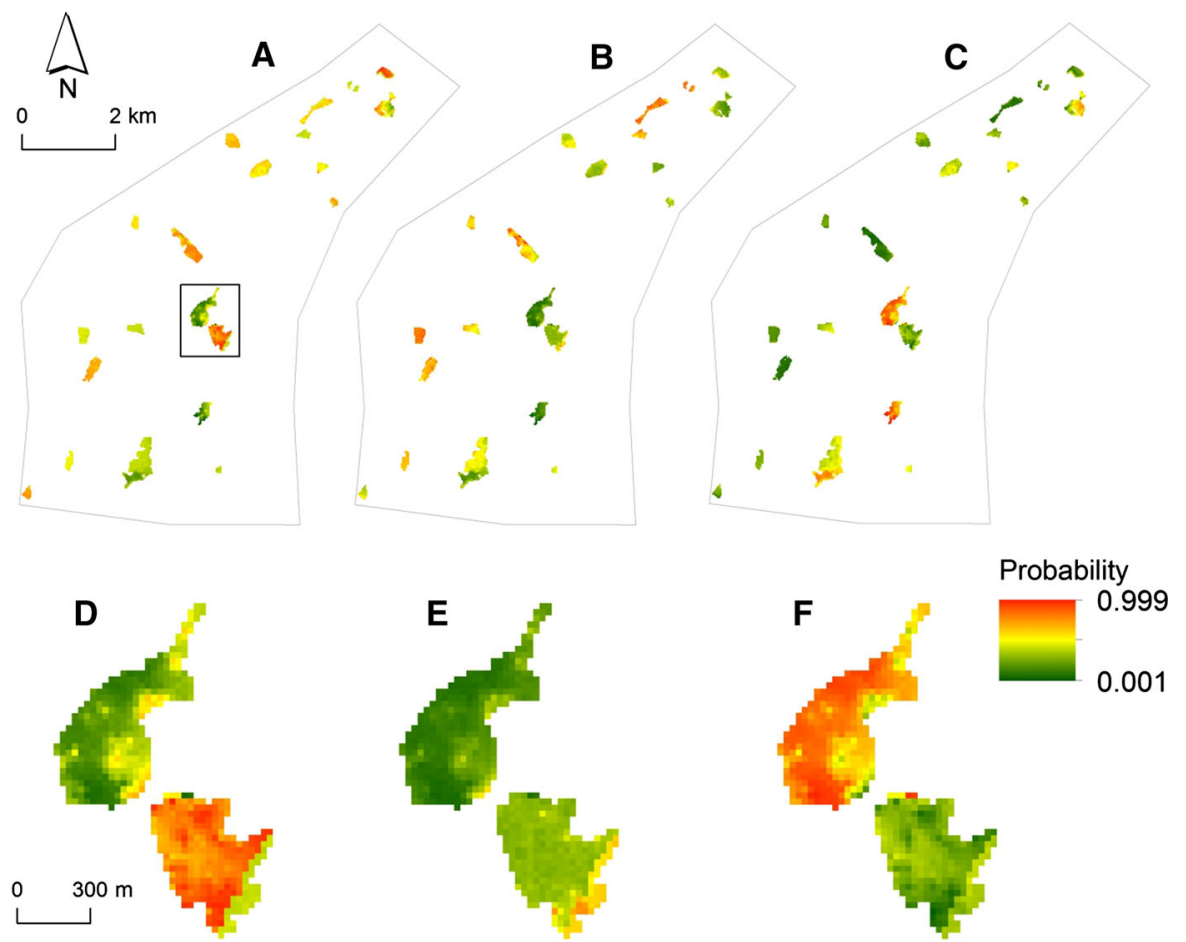

laser-beam penetration capabilities. Likewise, Hodgson and Bresnahan (2004) and Hodgson et al. (2003) found elevation errors to be much higher for shrubs compared to other types of vegetation. Reutebuch et al. (2003) obtained the MAE of field-measured and LiDAR-derived terrain elevations within forests as high as $0.31 \mathrm{~m}$. Similarly, in our research, the upward shift for alder and willow encroachments was also observed and was as high as $0.24 \mathrm{~m}$ on average $\left(\sigma_{k}=0.35 \mathrm{~m} ; \mathrm{MAE}=0.32 \mathrm{~m}\right)$. One should also consider that the GNSS techniques used in this study due to the specifics of forest areas and high shrubberies could not provide precise information compared to open areas for DTM creation (Ordóñez Galána et al. 2011). This resulted from the negative influence of dense crown cover and wood biomass on the propagation of the GPS signal (Wężyk 2015). Similar issues were identified by numerous authors within areas covered with low vegetation, where laser measurements have a systematic positive height shift compared to the ground surface (e.g., Pfeifer et al. 2004). Hodgson and Bresnahan (2004) compared the LiDAR data with total station and rapid-static GPS measurements. The RMSE for the LiDAR data ranged from $0.22 \mathrm{~m}$ for low grass, $0.19 \mathrm{~m}$ for high grass, $0.23 \mathrm{~m}$ 
for brush and low trees and up to $0.26 \mathrm{~m}$ for deciduous forest. Evans and Hudak (2007) obtained elevation differences equal to $0.31 \mathrm{~m}$ for high canopy cover and $0.17 \mathrm{~m}$ for low canopy cover. Myszkowski et al. 2009 obtained an upward shift equal to $0.29 \mathrm{~m}$ for the low vegetation up to $0.2 \mathrm{~m}$. The main influencing factor here was vegetation height, as the scanning density was very large $-0.15 \mathrm{~m}$ and 12 points $/ \mathrm{m}^{2}$. In our research, the highest (but similar) upward shifts for low vegetation were observed in sedges (Caricetum gracilis) and reeds (Phragmitetum australis and Glycerietum maximae) and on average were equal to $0.15 \mathrm{~m} \quad\left(\sigma_{k}=0.40 \mathrm{~m} ; \mathrm{MAE}=0.34 \mathrm{~m} ; \mathrm{RMSE}=\right.$ $0.41)$ and $0.16 \mathrm{~m}\left(\sigma_{k}=0.33 \mathrm{~m} ; \operatorname{MAE}=0.26 \mathrm{~m}\right.$; RMSE $=0.34)$ respectively. Different results were obtained for Caricetum appropinquatae, for which the average elevation difference was $-0.10 \mathrm{~m}\left(\sigma_{k}=\right.$ $0.69 \mathrm{~m} ; \mathrm{MAE}=0.52 \mathrm{~m}$; RMSE $=0.61)$ with a range of values between -1.27 and $0.64 \mathrm{~m}$. When such sedges create compact tussocks, the results can be influenced on the one hand by mistakenly performed measurement of the ground surface with the GNNS RTK method (at the top or between tussocks) and on the other hand by the difficulties of generating DTM with a laser beam, originating once from the top of the tussock and once from the area between them. The largest elevation differences $(-0.38 \mathrm{~m}$ on average; with a range of values from -1.75 to $1.69 \mathrm{~m}$ ) and the highest mean absolute error (MAE $=0.77 \mathrm{~m}$; RMSE $=0.83 ; \sigma_{k}=0.84 \mathrm{~m}$ ) were observed in the class of 'mown meadow/grazed pasture'. The disagreement between ALS-LiDAR and DGPS could have resulted from generalizing $1 \mathrm{~m}$ DTM into the $25 \mathrm{~m}$ DTM used in this paper to keep the final DTM compatible with the grid size applied to the MODFLOW model. The possible errors in DTM creation in this class could have been caused by the presence of dense drainage network overgrown by bushes: generalization of $1 \mathrm{~m}$ DTM into the coarser resolution multiplied the error of the terrain elevation in different land-cover classes. The last return values were obtained on the one hand from the ditches and on the other hand from the bushes, which then had an impact on the resulting DTM. This aspect has so far seldom been considered in the literature. In light of the presented results, we advise the careful interpretation

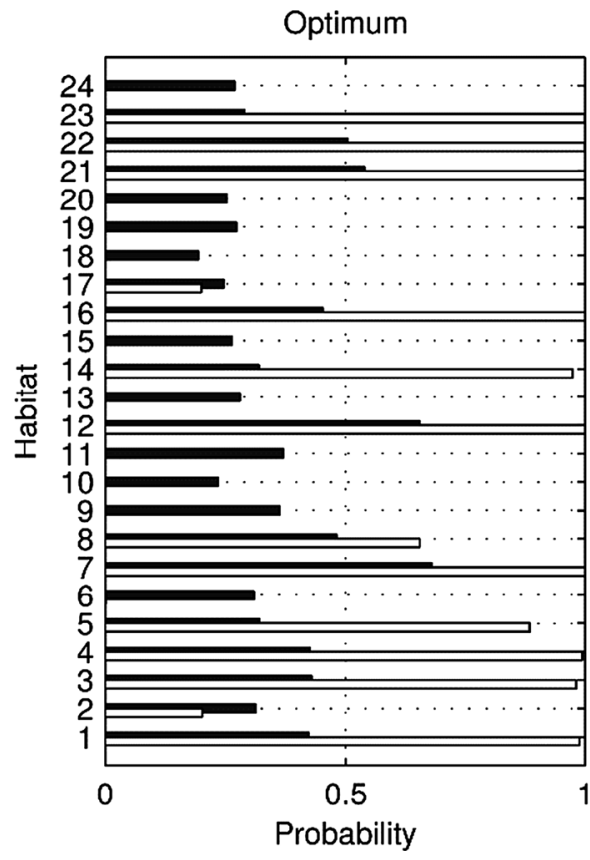

Fig. 6 Confidence intervals of HIS scores computed for grid nodes (spatially diverse) and averaged ground water depths for 24 plant communities (habitat: 1-6 Caricetum appropinquatae; 7-8 Caricetum gracilis; 9-12 Glycerietum maximae; 13-15, 17 mosaic of alder and willow encroachments; 16 mixed forest; 18

\section{Tolerance}

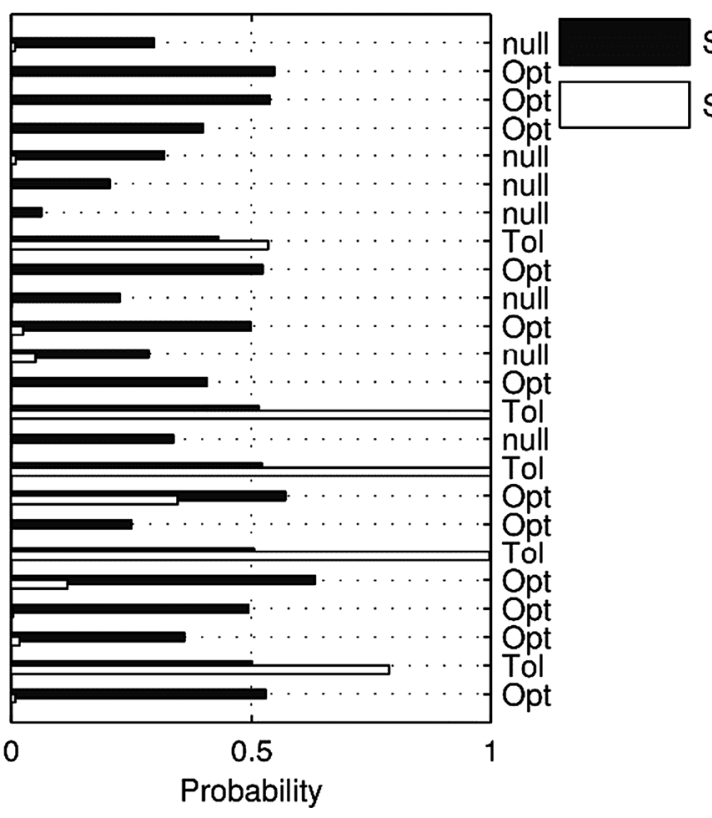

19 Phragmitetum australis; 20 mown meadow/pasture; 21 mixed sedges and grasses; 22-24 mosaic of loose tussock and tussock sedges); Opt, Tol and null-stand respectively for the optimal, tolerance and null HSI score derived for undisrupted DEM with averaged values 
of both LiDAR-DEM-based and GNSS RTK-based ground elevation approximations in densely drained areas of peatlands.

The total hydraulic heads of groundwater calculated with the developed MODFLOW-based model changed only to an insignificant extent with respect to the implemented variability of terrain elevation in the Monte Carlo exercise we performed. The $\sigma_{k}$ obtained from the modelled total hydraulic heads in the ensemble of 10,000 simulations, which reached $0.003 \mathrm{~m}$, indicates a negligibly small sensitivity of the model to changing geometry of the domain, referred to as the use of variable DEMs. This result remains logical and obvious, as the developed MODFLOW model did not account for unsaturated zone flow simulation, where the modification of terrain elevation is likely to affect the results of groundwater head computation to a more decent extent by changing the thickness of the unsaturated zone. However, we consider this observation relevant for approaches that use MODFLOW with additional packages that are capable of simulating even roughly-the unsaturated zone flow (Grygoruk et al. 2014). In the developed model, terrain elevation affects computed total heads in cases in which total hydraulic heads exceed ground level. This observation remains important when head-dependent flux boundary conditions are applied (e.g., DRAIN package), for which water flux remains a function of terrain elevation and actual groundwater level. Our model simulates steady-state, average conditions from a multi-year period. Although we simulate field conditions of riparian wetlands, in our case, only a few cells of the model faced conditions of groundwater seepage to the level reaching elevations above the ground. To keep the model relatively simple to allow verification of the initial hypotheses, we did not account for the quantification of uncertainties associated with varying elevations of, e.g., the bottom of the river in the RIV package applied. However, we consider this an important topic for further analyses, especially in local, river-stretchoriented approaches accounting for modelling groundwater-surface water interactions, in which the uncertainty of river bottom elevation may become an issue affecting the modelling results to a considerable extent.

Contradictory to the low uncertainty of modelled total hydraulic heads with respect to the variable terrain elevations, discussed above, the uncertainty analysis of calculated groundwater depths against the changing terrain elevations that resulted from the errors of DEM performed in our study revealed high sensitivity of this parameter to the changing terrain elevations tested in the Monte Carlo approach. Our estimated HSI score referred to the modelled groundwater depths for both undisrupted DEM and the anticipated uncertainty of the DEM in cases of habitats that changed significantly (Table 3; Fig. 6). For example, habitat conditions for biota approached by the HSI score in habitat no. 17 (Mosaic of alder and willow encroachments located within the range of presence of Aquila clanga) were described as 'tolerant' in the case in which undisrupted DEM was considered. Accounting for DEM uncertainty and analysing hydrological conditions within this habitat with the use of an averaged $h$ for the entire habitat indicated that the probability of having a 'tolerant' value of the HSI reached only 0.53 . At the same time, the probabilities of reaching the 'optimum' and 'unsuitable' values of HSI within this habitat were as high as 0.20 and 0.27 , respectively (Table 3 ). In the case of spatially distributed values of particular probabilities of $h$ occurrence in the grid nodes of the habitats analysed, the results of an HSI score estimation are even more variable. In the above-discussed habitat no. 17, the probability of HSI being unsuitable for the biota analysed reaches 0.47 and is nearly equal to the probability of HSI being optimal (0.46). In this case, the interpretation of HSI, which was unambiguous and explicit ('tolerant') for undisrupted DEM, has lost its unilaterality and remained defined as optimum (with the probability of $46 \%$ ), tolerant $(7 \%)$ and, surprisingly, unsuitable (47\%). In some cases, in the habitats analysed, the HSI value 'unsuitable' was assigned for both undisrupted DEM and the analysis of the probability of $h$ averaged over a particular community area (i.e., habitat no. 10 - Glycerietum maximae).

However, when the probability of a particular $h$ occurrence within the individual grid nodes was analysed, the 'tolerant' and 'optimum' values of HSI were defined with the probability of 0.34 and 0.09 respectively. However, hydrological conditions defined as 'unsuitable' are expected with the probability of 0.53 . Switching from the analyses of the probability of $h$ averaged over habitats to probabilities of $h$ in particular grid nodes, the results in the majority of habitats analysed the changed probabilities of 'tolerant' and 'optimal' values of HSI (Fig. 5). For example, in habitat no. 14 (Mosaic of alder and willow 
encroachments, range of presence of Anser albofrons, Crex crex, Gallinago gallinago and Acrocephalus paludicola), the dominant 'optimum' hydrological conditions for biota (a probability of 0.97 in the approach when $h$ is averaged over the habitat) remain 'optimum' only for some $56 \%$ of the habitat, when the probability of particular values of $h$ in particular grid nodes is analysed (Table 3). This reveals that measures defined in the same manner as the proposed HSI are sensitive to the placement of the averaging operator-prior to or after the measure.

Assessing a habitat's hydrological conditions on the basis of groundwater depth remains widely applicable in managing wetland environments both in the study area (Chormański et al. 2009) and worldwide (Mitsch and Gosselink 2015). Our discussion of the results of the relevance of DEM quality on groundwater modelling interpretations indicate that neglecting the uncertainty of DEM and different approaches to groundwater depth assessment within wetlands may result in biased ecohydrological analyses. We conclude that groundwater-modelling-based decision support approaches in wetland management can result in wrong decision-making if the quality of the applied DEM is not addressed in studies referring to groundwater depths: habitats that are foreseen to be too dry can in fact be too wet.

\section{Conclusions}

(1) We compared terrain-elevation data originating from the ALS-LiDAR DEM and from field measurements performed with the use of GNSS GPS to reveal errors in the DEM elevation data. We revealed that the MAE of DEM within the floodplain wetland that was analysed ranged from 0.23 to $0.77 \mathrm{~m}$ ( $\sigma_{k}$ varied from 0.26 to $0.84 \mathrm{~m}$ respectively) and depended on the types of vegetation.

(2) We revealed that the uncertainty of DEM influences MODFLOW-computed groundwater heads in steady-state conditions when the unsaturated zone is not accounted for and groundwater seepage to the surface of the model occurs only to a limited extent. The standard deviation of water levels computed in these conditions did not exceed $0.003 \mathrm{~m}$.
(3) We found that the uncertainty of DEM significantly influenced the results of the assessment of the habitat's hydrological conditions expressed as groundwater depths, herein approximated by the HSI score. In extreme cases, although the averaged HSI assessed in the deterministic manner was defined as 'unsuitable', in a probabilistic approach (grid-cellscale estimation), it reached values of $40 \%$ probability, signifying 'optimum' or 'tolerant'. We stress that model-derived average groundwater levels that referred to terrain elevations obtained from the DEM remains a reason for potential, significant errors in the quantification of the hydrological parameters of habitats referred to as depth to groundwater table.

(4) For the 24 habitats analysed, we revealed vast differences between the HSI score calculated for the individual grid cells of the model and the HSI score computed as an average value from the set of grid cells located within the habitat patches. This indicates the problem of averaging in the elaboration of measures similar to the HSI.

(5) When using groundwater flow models in which DEM was used to determine the geometry of the model domain, magnitudes of groundwater depths referred to as differences between the minimum and maximum values of groundwater table elevations over a certain period remain the most reliable and least uncertain hydrological predictor of habitat conditions.

(6) We conclude that groundwater-modellingbased decision support approaches to wetland assessment can result in incorrect management if the quality of DEM used in the analyses is not addressed in studies referring to groundwater depths: habitats that have been foreseen to be too dry can eventually remain too wet.

Acknowledgements Research was done in the framework of the Pol-Nor/209804/42/2013 project "Integrated Wetland model: A tool for management adaptation in protected wetlands" (WETFLOD), funded by Polish-Norwegian Research Programme, Small Grant Scheme, implemented by the National Centre for Research and Development. We wish to acknowledge the editor and anonymous reviewers for their thoughtful comments that helped us to improve the manuscript. 
Open Access This article is distributed under the terms of the Creative Commons Attribution 4.0 International License (http:// creativecommons.org/licenses/by/4.0/), which permits unrestricted use, distribution, and reproduction in any medium, provided you give appropriate credit to the original author(s) and the source, provide a link to the Creative Commons license, and indicate if changes were made.

\section{References}

Aguilar FJ, Mills JP, Delgado J, Aguilar MA, Negreiros J, Pérez JL (2010) Modelling vertical error in LiDAR-derived digital elevation models. ISPRS J Photogramm Remote Sens 65:103-110

Archer G, Saltelli A, Sobol I (1997) Sensitivity measures ANOVA-like techniques and the use of bootstrap. J Stat Comput Simul 58:99-120

Banaszuk H (2004) General description of Biebrza Valley and Biebrza National Park. In: Banaszuk H. (Ed.) Biebrza Valley and Biebrza National Park. Wydawnictwo Ekonomia i Środowisko Białystok (in Polish)

Banaszuk P, Kamocki AK, Zarzecki R (2016) Mowing with invasice machinery can affect chemistry and trophic state of rheophilous mire. Ecol Eng 86:31-38

Batelaan O, Kuntohadi T (2002) Development and application of a groundwater model for the Upper Biebrza Basin. Ann Warsaw Univ Life Sci SGGW Land Reclam 33:57-69

Berezowski T, Chormański J, Batelaan O (2015) Skill of remote sensing snow products for distributed runoff prediction. J Hydrol 524:718-732

Bleuten W, Schermers G-T (1994) Hydrological modelling of a part of the Middle Basin of the Biebrza valley. In: Wassen MJ, Okruszko H (eds) Towards protection and sustainable use of the Biebrza wetlands: exchange and integration of research results for the benefit of a Polish-Dutch joint research plan. Utrecht, Institute for Land Reclamation Grassland Farming, Falenty, Commission of the European Communities, Brussels, Department of Environmental Studies, Utrecht University, pp 51-58

BNP (2015) Biebrza national park natura 2000 management plan. Manuscript and supportive spatial data. Biebrza National Park, Osowiec-Twierdza, Poland

Bradley C (2002) Simulation of the annual water table dynamics of a floodplain wetland Narborough Bog UK. J Hydrol 261:150-172

Brandyk A, Kiczko A, Majewski G, Kleniewska M, Krukowski M (2016) Uncertainty of Deardorff's soil moisture model based on continuous TDR measurements for sandy loam soil. J Hydrol Hydromech 64:23-29

Caldwell PV, Vepraskas MJ, Gregory JD, Skaggs RW, Huffman RL (2011) Linking plant ecology and long-term hydrology to improve wetland Restoration success. Trans ASABE 54:2129-2137

Chormański J, Kardel I, Mirosław-Świątek D, Grygoruk M, Okruszko T (2009) Management Support System for wetlands protection; Red Bog and Lower Biebrza Valley case study. Hydroinform Hydrol Hydrogeol Water Res IAHS Publ 331:423-431
Evans JS, Hudak AT (2007) A multiscale curvature algorithm for classifying discrete return LiDAR in forested environments. IEEE Trans Geosci Remote Sens 45:1029-1038

Fortuniak K, Pawlak W, Bednorz L, Grygoruk M, Siedlecki M, Zieliński M (2017) Methane and carbon dioxide fluxes of a temperate mire in Central Europe. Agric For Meteorol 23:306-318

Grygoruk M (2013) Variability of groundwater flow as a factor of mire ecohydrological evolution. Example of Czerwone Bagno. VUB Hydrologie 74222 pp. PhD. Thesis Vrije Universiteit Brussel Belgium

Grygoruk M, Mirosław-Świątek D, Kardel I, Okruszko T, Michałowski R, Kwiatkowski G (2011) Analysis of pastpresent hydrological phenomena in the Biebrza Valley. HABIT-CHANGE 4.4 .2 report 29 pp. http://www2.ioer. de/download/habit-change/HABIT-CHANGE_4_4_2\%20 hydrologic_phenomena.pdf

Grygoruk M, Mirosław-Świątek D, Chrzanowska W, Ignar S (2013) How much for water? Economic assessment and mapping of floodplain water storage as a catchment-scale ecosystem service of wetlands. Water 5:1760-1779

Grygoruk M, Batelaan O, Mirosław-Świątek D, Szatyłowicz J, Okruszko T (2014) Evapotranspiration of bush encroachments on a temperate mire meadow-a nonlinear function of landscape composition and groundwater flow. Ecol Eng 73:598-609

Grygoruk M, Bańkowska A, Jabłońska E, Janauer GA, Kubrak J, Mirosław-Świątek D, Kotowski W (2015) Assessing habitat exposure to eutrophication in restored wetlands: model-supported ex-ante approach to rewetting drained mires. J Environ Manag 152:230-240

Grzywaczewski G, Cios S, Sparks TH, Buczek A, Tryjanowski $\mathrm{P}$ (2014) Effect of habitat burning on the number of singing males of the Aquatic Warbler Acrocephalus paludicola. Acta Ornithol 49:175-182

Grzywaczewski G, Bochniak A, Wiącek J, Łapiński P, Morelli F (2017) Water on the fen mire as a problem in the protection of globally threatened species: long term changes in Aquatic Warbler numbers. Pol J Environ Stud 26:1-6

Harbaugh AW (2005) MODFLOW-2005 the U.S. Geological Survey modular ground-water model-the Ground-Water Flow Process. U.S. Geological Survey Techniques and Methods 6-A16

Hassan AE, Bekhit HM, Chapman JB (2008) Uncertainty assessment of a stochastic groundwater flow model using GLUE analysis. J Hydrol 362:89-109

Hodgson ME, Bresnahan P (2004) Accuracy of airborne Lidar derived elevation: empirical assessment and error budget. Photogramm Eng Remote Sens 70:331-339

Hodgson ME, Jensen JR, Schmidt L, Schill S, Davis B (2003) An evaluation of LiDAR- and IFSAR-derived digital elevation models in leaf-on conditions with USGS level 1 and level 2 DEMs. Remote Sens Environ 84:295-308

Hunter GJ, Goodchild MF (1997) Modeling the uncertainty of slope and aspect estimates derived from spatial databases. Geogr Anal+ 29:35-49

Kiczko A, Romanowicz RJ, Osuch M, Karamuz E (2013) Maximising the usefulness of flood risk assessment for the River Vistula in Warsaw. Nat Hazards Earth Syst Sci 13:3443-3455 
Koreny JS, Mitsch WJ, Bair ES, Wu XY (1999) Regional and local hydrology of a created riparian wetland system. Wetlands 19:182-193

Kossowska-Cezak U (1984) Climate of the Biebrza ice-marginal valley. Pol Ecol Stud 10:3-4

Kotowski W, Jabłońska E, Bartoszuk H (2013) Conservation management in fens: Do large tracked mowers impact functional plant diversity? Biol Conserv 167:292-297

Liu X, Hu P, Hu H, Sherba J (2012) Approximation theory applied to DEM vertical accuracy assessment. Trans GIS 16:397-410

Maciorowski G, Mirski P, Kardel I, Stelmaszczyk M, MirosławŚwiątek D, Chormański J, Okruszko T (2014) Water regime as a key factor differentiating habitats of spotted eagles Aquila clanga and Aquila pomarina in Biebrza Valley (NE Poland). Bird Study 62:120-125

Mirosław-Świątek D, Grygoruk M, Michałowski R, SzporakWasilewska S, Ignar S (2016a) Unravelling uncertainties of water table slope assessment with DGPS in lowland floodplain wetlands. Environ Monit Assess 188(11): 625; doi: 10.1007/s10661-016-5642-3

Mirosław-Świątek D, Szporak-Wasilewska S, Michałowski R, Kardel I, Grygoruk M (2016b) Processing airborne laser scanning data to generate accurate digital terrain model for floodplain wetlands. J Appl Remote Sens 10(3):036013. doi:10.1117/1.JRS.10.036013

Mirosław-Świątek D, Szporak-Wasilewska S, Grygoruk M (2016c) Assessing floodplain porosity for accurate quantification of water retention capacity of near natural riparian ecosystems-a case study of the Lower Biebrza Basin. Ecol Eng 92:181-189

Mitsch WJ, Gosselink JG (2015) Wetlands 5th ed. Wiley, Hoboken, $456 \mathrm{pp}$

Myszkowski M, Ksepko M, Gajko K (2009) Detekcja liczby drzew na podstawie danych lotniczego skanowania laserowego (Tree number detection based on airborne laser scanning data). Archiwum Instytutu Inżynierii Lądowej 6:63-72 (in Polish)

Okruszko T (2005) Kryteria hydrologiczne w ochronie mokradeł. Rozprawy Naukowe i Monografie SGGW 297. Wydawnictwo SGGW Warszawa

Opdekamp W, Beauchard O, Backx H, Franken F, Cox TJS, van Diggelen R, Meire P (2012) Effects of mowing cessation and hydrology on plant trait distribution in natural fen meadows. Acta Oecol 39:117-127

Oppel S, Marczakiewicz P, Lachmann L, Grzywaczewski G (2014) Improving Aquatic Warbler population assessments by accounting for imperfect detection. PLoS ONE 9:e94406

Ordóñez Galána C, Rodríguez-Pérezb JR, Martínez Torresc J, García Nietod PJ (2011) Analysis of the influence of forest environments on the accuracy of GPS measurements by using genetic algorithms. Math Comput Model Math Models Addict Behav Med Eng 54(7-8): 1829-1834

Pfeifer N, Gorte B, Elberink SO (2004) Influences of vegetation on laser altimetry - analysis and correction approaches. Int Arch Photogramm Remote Sens Spat Inform Sci XXXVI8/W2: 283-287

Polakowski M, Broniszewska M, Goławski A (2014) A comparison of two methods of duck census during the spring migration in a widely flooded river valley. Ornis Pol 55:279-289

Reutebuch SE, McGaughey RJ, Andersen HE, Carson WW (2003) Accuracy of a high-resolution lidar terrain model under a conifer forest canopy. Can J Remote Sens 29:527-535

Richter BD, Baumgartner JV, Powell J, Braun DP (1996) A method for assessing hydrologic alteration within ecosystems. Consrev Biol 10:1163-1174

Romanowicz RJ, Kiczko A (2016) An event simulation approach to the assessment of flood level frequencies: risk maps for the Warsaw reach of the River Vistula. Hydrol Process 30:2451-2462. doi:10.1002/hyp.10857

Slapinska M, Chormański J, Glińska-Lewczuk K (2016) Relation between inundation frequency and habitat conditions of loodplain lakes-a case study of the lowland Biebrza River (NE Poland). Environ Eng Manag J 15:1311-1321

Vepraskas MJ, Caldwell PV (2008) Interpreting morphological features in wetland soils with a hydrologic model. Catena 73:153-165

Wassen MJ, Okruszko T, Kardel I, Chormanski J, Swiątek D, Mioduszewski W, Bleuten W, Querner EP, El Kahloun M, Batelaan O, Meire P (2006) Ecohydrological functioning of the Biebrza wetlands: lessons for the conservation and restoration of deteriorated wetlands. In: Bobbink R, Beltman B, Verhoeven JTA, Wigham DF (eds) Wetlands: functioning biodiversity conservation and restoration. Springer, Berlin, pp 285-310

Wężyk P (2015) Making the invisible visible-the DTM modelling in complex environments. In: Jasiewicz J, Zwoliński Z, Mitasova H, Hengl T (eds) Geomorphometry for Geosciences. Adam Mickiewicz University in Poznań-Institute of Geoecology and Geoinformation International Society for Geomorphometry Poznań, pp 57-60

Winston RB (2009) ModelMuse-A graphical user interface for MODFLOW-2005 and PHAST: U.S. geological survey techniques and methods 6-A29, p 52

Wu J, Zeng X (2013) Review of the uncertainty analysis of groundwater numerical simulation. Chin Sci Bull 58:3044-3052

Zhou DM, Gong HL, Liu ZL (2008) Integrated ecological assessment of biophysical wetland habitat in water catchments: linking hydro-ecological modelling with geo-information techniques. Ecol Model 214:411-420 